\title{
PERAKENDE TERAPI
}

\author{
Kumru UYAR ${ }^{1}$
}

\author{
Received (Başvuru Tarihi): 28/02/2019 \\ Accepted (Kabul Tarihi): 20/03/2019 \\ Published Date (Yayın Tarihi): 25/03/2019
}

\section{$\ddot{O} Z$}

Bu çalı̧̧manın öncelikli amacı, Türkçe literatürde yeni olan terapi tüketimi kavramının tanımlanmasıdır. Bir diğer amacı ise, kişilik özelliklerine göre perakende terapinin farkllllk gösterip göstermediğini ortaya koymaktır. Türkçe literatürde perakende terapisi ile ilgili yapılmış herhangi bir çallş̧maya rastlanamamıştır. Çalışmada kişilik özellikleri 5 faktör kişilik özellikleri temel alınarak incelenmişstir. Araştırma kolayda örnekleme yöntemi ile yapılmuş ve 386 katılımcıdan veriler yüz yüze anket yöntemi ile toplanmıı̧str. Çalışmada veri toplama araçları olarak Terapi tüketim Ölçeği ve Beş Faktör Kişilik Ölçeği geçmiş çalı̧̧malarından uyarlanarak kullanılmıştır. Toplanan veriler SPSS 22 paket programı ile analiz edilmiştir. Elde edilen bulgulara göre nevrotik ve dürüst kişilik özelliklerine göre perakende terapinin farklllı gösterdiği tespit edilmiştir. Bu sonuçlara göre nevrotik ve dürüst kişilik özellikleri fazla olan bireylerin perakende terapiyi daha olumlu algıladikları söylenebilir. Diğer kişilik özelliklerinde ise perakende tüketim açısından istatistiksel olarak anlamlı bir farklllı̆ga rastlanmamıştır. Araştırmanın Türkçe literatüre yeni bir kavram kazandırması ve gelecekte yapılacak başka çalışmalarla konunun zenginleşmesi beklenmektedir.

Anahtar Kelimeler: Perakende Terapi, Telafi Edici Tüketim, Duygu Durum Düzenleyici Tüketim, Beş Faktör Kişilik

JEL Kodlart: M10, M30, M31

\section{RETAIL THERAPY}

\begin{abstract}
The primary objective of this study is to define the concept of the therapy study which is new in Turkish literature. Another aim of the study is to reveal whether or not retail therapy differs in personality characteristics. In the Turkish literature, no studies on retail therapy have been found. The personality traits of the study were determined based on the 5 factor personality traits. The research was carried out by simple random sampling method and data from 386 participants were collected by face to face survey method. In this study, the Therapy Consumption Scale and the Five Factor Personality Scale were used as data collection tools. The collected data were analyzed with SPSS 22 package program. According to the findings, it was determined that retail therapy differed according to neurotic and honest personality traits. According to these results, it can be said that individuals who have more neurotic and honest personality traits perceive more positively against retail therapy. In the other personality traits, no statistical difference was found in terms of retail consumption. It is expected that the study will gain a new concept in Turkish literature and the subject will be enriched with other studies in the future.
\end{abstract}

Keywords: Retail Therapy, Compensatory Consumption, Emotional Regulation Consumption, Five Factor Personality

JEL Codes: M10, M30, M31

${ }^{1}$ Dr.Öğr. Üyesi, Nuh Naci Yazgan Üniversitesi, kumruuyar@hotmail.com

http://orcid.org/0000-0002-2604-5317 


\section{GíRiş}

İnsanların davranışlarını ve eylemlerini belirlemede duyguların hayati bir rolü vardır. Son yıllarda, pazarlama akademisyenleri, duyguların tüketim davranışında da son derece etkili olduğunu vurgulamaktadırlar. Tüketici duyguları alışverişle yakından ilişkilidir. Günümüzde tüketim, Özcan'ın da (2007, s.263) belirttiği gibi, insanları gündelik sorunlarından uzaklaştıran, adeta ruhsal ve zihinsel bir terapi ortamı sağlamaktadır. Alışveriş deneyimleri artık sadece bir ürün satın almakla ilgili değildir. Çağdaş tüketim tarzında, tüketiciler olumsuz ruh hallerini hafifletmek için sıklıkla alışveriş yapmaktadırlar (Ko, Chun, Song \& Mattila, 2015, s.40). Türkçe literatürde perakende terapisi ile ilgili yapılmış herhangi bir çalışmaya rastlanamamıştır. Uluslararası literatürde ise birkaç çalı̧̧mada konu ele alınmıştır. Ancak hiçbir çalışmada perakende terapisi kişilik ile birarada incelenmemiştir. Tüketici davranışlarında etkili konulardan bir diğeri de kişiliktir. Kişilik tüketici davranışı ile ilgili pek çok konuda etkilidir. Bu çalışmada, katılımcıların kişilik özellikleri Costa ve McCrae (1985) tarafından geliştirilen ve kişiliği açıklamada yaygın olarak ele alınan, Büyük Beş Faktör Modeline göre tanımlanmaktadır. Bu modele göre kişilik faktörleri; dışa dönüklük, duygusal dengesizlik, yumuşak başlllık, dürüstlük ve deneyime açıklık olarak birçok çalışmada doğrulanmıştır. Gökdeniz, Durukan ve Bozacı, (2012)'nin belirttiği gibi Beş faktör kişilik ölçeğinin birçok farklı ülke ve kültürde güvenilir şekilde uygulanması (Kanada, Çin, Çek Cumhuriyeti, Almanya, Yunanistan, Finlandiya, Hindistan, Japonya, Kore, Filipinler, Polonya ve Türkiye) bu birkaç değişkenin insan kişiliğinin önemli bileşenleri olduğu görüşünü desteklemektedir.

Çalışmada izlenen yol şu şekildedir. Bu kısa giriş bölümünden sonra, terapi tüketimi kavramı ve beş faktör kişilik modeli tartı̧ılmaktadır. Sonrasında ise araştırmanın hipotezleri sunulmaktadır. Üçüncücü bölümde, araştırmanın metodolojisine ve uygulamaya yer verilmektedir. Son bölümde ise araştırmanın sonuçları tartışılmakta ve araştırmanın kısıtları doğrultusunda bu alandaki akademisyen ve araştırmacılara gelecek çalışmaları için önerilerde bulunulmaktadır.

\section{KAVRAMSAL ÇERÇEVE}

Bu bölümde araştırmanın temel değişkeni olan perakende terapi kavramı ile çalışmada kullanılan beş faktör kişilik modeli açıklanmaktadır. 


\subsection{Perakende Terapi}

Tüketiciler alışveriş faaliyeti sonucu kendilerini mutlu hissedebilirler ve alışveriş ortamının olumsuz yönlerini görmezden gelebilirler. Perakende terapisi tüketicilerin kendilerini daha iyi hissetmek için yaptıkları alışverişlerdir. Benzer şekilde Rath (2010) perakendecilik terapisini, alışverişin hemen ardından bir kişinin kendini daha iyi hissetmesini sağlamak için yürütülen stratejik bir çaba olarak tanımlamaktadır. Tüketiciler alışverişi, sorunlarından kaçmanın, stresle başedebilmenin veya olumsuz ruh halini düzeltmenin bir yolu olarak görebilirler. Babin, Darden ve Griffin'nin (1994) çalışmalarında belirttikleri gibi tüketiciler alışverişi kendi kendini tatmin edici ve terapötik bir faaliyet olarak kabul edebilirler. Tüketim, gerçek dünyayla başa çıkmak için geliştirilen, kurumsallaşmış bir toplumsal savunma stratejisi olarak görülebilir; bireyler tüketim yoluyla, dünyayla kurdukları ilişkilerden kaynaklanan kaygı ve korkulardan sakınabilerek; bu tehditleri tecrit edebilirler (Robins, 1999, s.179). Jamal, Davies, Chudry ve Al-Marri, (2006) benzer şekilde, tüketicilerin alışverişi, günlük hayatlarının rutinlerini unutabilecekleri alternatif bir aktivite olarak algıladıklarını vurgulamaktadırlar. Gardner ve Rook (1988) çalışmalarında alışverişin psikolojik yararlar sağlayabileceğine dair bazı kanıtlar bulmuşlardır. Faber ve Christenson (1996) günlük araştırmaları sonucunda insanların alışveriş yaparken, alışverişe çıkmadan hemen öncesine göre daha az üzgün olduklarını tespit etmişlerdir. Benzer şekilde Atalay ve Meloy’un (2011) yürüttükleri günlük çalışmada, katılımcıların çoğu ruh halini düzeltme motivasyonu ile yaptıkları alımlarında olumlu duygular bildirmişlerdir.

Rick, Pereira ve Burson (2014) yürüttükleri deneysel çalışmada, perakende terapisinin tüketiciler tarafından başlangıçta, borçlanmayı arttırması, israfa sebep olması, etkisiz ve saçma bulunması gibi sebeplerle, olumsuz algılandığını belirtmişlerdir. Ancak, çalışmanın sonunda alışverişin, insanın çevresi üzerindeki kişisel kontrol hissini geri kazanmasına ve üzüntüyü azaltmasına yardımcı olabileceğini öne sürmüşlerdir.

Terapi tüketimi üzerinde çok az ampirik çalışma yapılmıştır. Mevcut terapi tüketimi çalışmalarında, araştırmacıların çoğu kalitatif yaklaşımlar kullanmış ve görüşmelerle veri toplamıştır (Kacen, 1998; Kang \& Johnson, 2010). Sadece sınırlı sayıda çalışmada (Yurchisin, Yan, Watchravesringkan \& Chen, 2008; Kang \& Johnson, 2011) araştırmacılar terapi tüketim davranışları için bir ölçek geliştirmeye çalışmışlardır. Ancak, Yurchisin vd. (2008) çalışmalarında ölçeğin geçerliliği ve madde üretim tekniği ile ilgili bilgi vermemişlerdir. 
Literatürde, perakende terapi kavramı, teorik olarak farklı davranışları açıklamak için kullanılarak iki temel bakış açısı ile incelenmektedir: Bunlardan ilki duygu durum düzenleyici tüketim (Babin vd., 1994; Kacen, 1998; Kacen \& Friese, 1999; Luomala, Kumar, Worm \& Singh, 2004; Yurchisin vd., 2008; Kang \& Johnson, 2010; 2011; Kemp \& Kopp, 2011; Atalay \& Meloy, 2011; Rick vd., 2014) ve ikincisi ise telafi edici tüketimdir (Woodruffe-Burton, 1997; 1998; Woodruffe-Burton \& Elliott, 2005; Yurchisin vd., 2008; Rucker \& Galinsky, 2008; Sivanathan \& Pettit, 2010; Kim \& Rucker, 2012; Kim \& Gal, 2014; Mandel, Rucker, Levav \& Galinsky, 2017).

Kang, Kim ve Johnson'ın (2011) vurguladığı gibi, her iki yaklaşım da terapi alışverişini anlamak için kullanılmış olsa da, telafi edici tüketim, ruh hali düzenleyici tüketimden daha fazla davranış içeren daha geniş bir yapı gibi görünmektedir, çünkü psikolojik eksiklikler sadece olumsuz ruh halini değil, doğrudan olumsuz ruh halleriyle ilgili olmayan diğer eksiklikleri de içermektedir (örneğin, genel özgüven eksikliği ve kendini gerçekleştirme). $\mathrm{Bu}$ nedenle, bu çalışmada, terapi tüketimini tanımlarken duygu durum düzenleyici tüketim boyutu temel alınmaktadır.

\subsubsection{Telafi Edici Tüketim}

Bazı araştırmacılar perakende terapiyi tüketicinin, benlik kavramını korumak ve düşük benlik saygısı veya algılanan güç kaybı gibi algılanan psiko-sosyal eksiklikleri telafi etmek için yapılan tüketim olarak tanımlamaktadırlar (Sivanathan \& Pettit, 2010; WoodruffeBurton, 1997; Woodruffe-Burton \& Elliott, 2005). Tüketiciler yaşamlarında tatmin edemedikleri bir ihtiyaç ya da arzu hissettiklerinde, algılanan eksikliği veya yoksunluğu telafi etmek için alışverişi stratejik bir "destek" olarak kullandıklarında bu davranış telafi edici tüketimdir (Woodruffe-Burton, 1998; Woodruffe-Burton, Eccless, \& Elliott, 2002). Yani, telafi edici tüketimde, algılanan psiko-sosyal eksiklikler alışveriş ve satın alma ile telafi edilmeye çalış1lır (Ko vd., 2015). Telafi edici tüketim, genellikle bireyler özgüven eksikliği yaşadıklarında ve olumsuz duygusal durumda olduklarında ortaya çıkmaktadır (Kacen \& Friese 1999; Woodruffe-Burton 1998). Yurchisin vd., (2008) olumsuz duygusal durumun telafi edici tüketim davranışlarıyla ilişkili ve benlik saygısı sorunlarının, katılımcıların telafi edici tüketim davranışı üzerinde daha fazla etkili olduğunu belirtmişlerdir. Telafi edici tüketim ile sarsılmış olan benlik saygısı onarılmaya çalışılır. Benzer şekilde Uyar ve Lekesizcan (2017) çalışmalarında benlik imajının tüketim üzerinde etkili olduğunu belirtmişlerdir. Bireyler benlik imajları ile yaşamları örtüşmediğinde aradaki farkı telafi etmeye çalışmaktadırlar. Morin (2015) başarısız öğrencilerin başarıyı temsil eden lüks marka 
saat ve çanta gibi ürünleri daha fazla tercih ettiğini, işinde terfi fırsatını kaçıran çalışanın lüks marka kıyafetler alarak kendisini başarılı hissetmeye çalıştığını vurgulamaktadır. Çalışmada ayrıca bu ürünlerin, kullanım sırasında bireylere başarısızlığı hatırlatarak, olumsuz bir etki yaratabileceğinden de bahsedilmektedir. Sonuç olarak, psikolojik yetersizlikler yaşayan bireyler, algıladıkları bu eksiklikleri telafi etmek için alışveriş yapabilirler. Aynı zamanda bu bireyler yaşadıkları bu tarz psikolojik zayıflıklar sebebiyle pazarlama çabalarına karşı daha savunmasız bir hal alabilirler.

\subsubsection{Duygu Durum Düzenleyici Tüketim}

Duygu düzenleme modelleri insanların sürekli olarak olumlu duyguları sürdürmeye ve olumsuz duygu durumlarını onarmaya çalıştıklarını varsaymaktadır (Andrade, 2005). Duygudurum düzenleyici tüketim ise, alışveriş ile olumsuz duygu durumlarını hafifletmek anlamına gelmektedir (Kacen, 1998). Stres, sıkıntı, mutsuzluk, hayalkırıklı̆̆ gibi olumsuz duygu durumundaki kimi bireyler rahatlamak için yemek yer, alkol kullanır, bağımlılık yaratıcı maddelere yönelirler. Bazı tüketiciler ise rahatlamak için alışverişe yönelebilirler. Alışveriş ile o anda kendilerini daha rahat ve mutlu hissederek kısa süreli de olsa sorunlarından uzaklaşabilirler. Lonsdale (1994, s.1) bu amaçla yapılan alışverişte satın alınan asıl ürünün insan ruhunu çok hızlı bir biçimde rahatlatabildiğini vurgulamaktadır. Bireyler farklı, terapatik alışveriş deneyimlerine katılarak duygusal durumlarını düzenleyebilirler (Krishen, Bui \& Peter, 2010). Duygu durum düzenleme stratejileri, alışveriş davranışlarıyla yakından ilişkilidir (Weinberg \& Gottwald, 1982; Thayer, Newman, McClain,1994).

Kang ve Johnson (2010) tüketicilerin terapi alışverişi sırasında dürtüsel satın alma gerçekleştirebildiklerini belirtmişlerdir. Rook ve Gardner bu tür davranış1; "terapatik ruh hali değişikliği taktiği” olarak adlandırmışlardır (1993, s.19). Luomala (1998), olumsuz ruh hallerinin tüketime bağlı faaliyetler yoluyla düzenlemesinin tüketicilerin yaşamlarının önemli bir parçası olduğunu ve tüketicilerin kendi kendilerine hediye vererek duygu durumlarını düzenlemeye çalıştıklarını tespit etmiştir (Luomala 1998, s.109). Atalay ve Meloy’da (2006) çalışmalarında bireylerin sadece kutlamalar için değil duygu durumlarını düzeltmek için de kendi kendilerine hediye verebildiğini belirtmiştir. Hatta bireylerin kendilerine aldıkları hediyelerin büyük bir kısmının duygu durumlarını düzenlemek için alındığını vurgulamışlardır. Çalışmalar kendine hediye davranışı ve telafi edici tüketimin, tüketicinin ruh halini düzenlemek için bir araç olarak kullanılabileceğini göstermiştir (Mick, DeMoss \& Faber 1992; Woodruffe-Burton,1997; 1998). 
Bui ve Kemp, (2013, s.158) perakende alışveriş terapisinin sadece geleneksel perakende satış biçimlerinde değil, aynı zamanda e-satışta da mevcut olabileceğini belirtmektedirler. Araştırmacılar, tüketicilerin gittikçe artan bir şekilde perakende satış terapisini sanal ortamlarda, evlerinin mahremiyetinde olumlu duygusal alışveriş deneyimleri oluşturmak için kullandıklarını da vurgulamaktadırlar. Underhill (1999) kadınların özellikle alışverişi perakende terapisi olarak kullandıklarını ve sıradan hayattan "kaçış" için alışveriş yapmaktan büyük zevk aldıklarını tespit etmiştir.

Atalay ve Meloy (2011), tüketicilerin perakende satış terapisi sırasında, genellikle normalde satın almadıkları, yüksek fiyatı ve modaya uygun giyim eşyalarını satın aldıklarını tespit etmişlerdir. Bunu destekler şekilde Son ve Chang, (2016) ürünlerin fiyatının perakende terapisi üzerinde etkisi olmadığını tespit etmiştir.

\subsection{Kişilik ve Beş Faktör Kişilik Modeli}

Kişilik, yıllardan beri sosyal bilimler alanında pek çok disiplin tarafından farklı yönleriyle ele alınmıştır. Bu araştırmalarda her disiplin kendi bakış açısıyla "insanların birbirinden neden farklı oldukları”, “aynı durumlar karşısında her insanın niçin farklı tepkiler gösterdiğị” sorularına cevap aramıştır. Atkinson, Atkinson ve Hilgard (1995), kişiliğii, bireyin fiziksel ve sosyal ortamla etkileşim şeklini ortaya koyan, düşünce, duygu ve davranışın ayırt edici ve karakteristik özellikleri şeklinde tanımlamışlardır. Kişilik kendine özgü ve ahenkli bir bütündür. Kişilik terimi, bireyi diğer bireylerden ayıran, onu eşsiz k1lan ve bireyin ilerdeki davranışlarına yönelik tahminlerimizin dayanağını oluşturan, göreceli olarak değişmez özelliklerini belirtmektedir (Yanbastı, 1991). Kişilik, bir bireyi diğerlerinden ayıran, duygu, düşünce, davranış ve tutumlarının bütünüdür (Köknel, 2005, s.19). Kişiliğin gelişmesinde insanın doğuştan getirdiği kalıtsal özelliklerle birlikte çevre faktörleri de etkilidir.

Kişiliği tanımlamada ve ölçmede çok farklı yaklaşımlar vardır. Uzun yıllar araştırmacılar kişiliği evrensel düzeyde sınıflandırabilecek bir model aramışlardır. $\mathrm{Bu}$ çalışmalar sonucunda elde edilen birbiriyle bağlantılı bulgular sonrasında, daha önceki sınıflandırmaların çoğunu açıklayan ve insan davranışlarını tanımlayabilen beş temel kişilik boyutu kabul görmüştür (Digman, 1990; John, 1990; McCrae \& John, 1992; Goldberg, 1993; Block, 1995). Kişilik literatüründe, Beş Faktör Kişilik Modeli (Büyük Beş Kişilik Modeli), küresel kişilik özelliklerinin önemli bir sınıflandırma şekli olarak ortaya çıkmıştır. Somer, Korkmaz ve Tatar, (2002) bu modeli Türkiye'ye uyarlayarak Beş Faktör Kişilik Envanterini (5FKE) geliştirmişlerdir. McCrae ve Costa, (1983-1985) çalışmalarının sonucunda kişiliğin 
beş boyutlu olduğunu ortaya koymuşlardır. Kişilikle ilgili beş faktör ve özellikleri şu şekildedir:

Duygusal dengesizlik (nevrotiklik): Korku, üzüntü, utanç, öfke, suçluluk ve iğrenme gibi olumsuz duyguları yaşama eğilimidir (Costa \& McCrae, 1992, s.15). Nevrotikliği yükssek kişiler, depresif, kaygılı, sabırsız, hüzünlü, güvensiz, gergin, sıklıkla duygusal iniş çıkışlar yaşayan, tedirgin, huzursuz, içine kapanık ve sinirli kişilerdir (Benet-Martinez \& John, 1998; Somer vd., 2002; Bacanlı, İlhan \& Aslan, 2009; Basım, Çetin \& Tabak, 2009). Mooradian ve Olver (1996) nevrotikliğin, kendini tatmin etme ve duygu durum yönetimi ile bağlantılı alışveriş motivasyonlarıyla ilgili olması gerektiğini belirtmişlerdir.

Dışa dönüklük: Dışa dönük kişiler sosyal bireylerdir, insanları, eğlenceyi, büyük grupları ve toplantıları severler. Aynı zamanda, hırslı, aktif ve konuşkanlardır (Costa \& McCrae, 1992, s.16; Somer vd., 2002, s.23). Bu boyutun iki önemli bileşeni hırs/tutku ve arkadaş canlısı olma özelliğidir (Barrick \& Mount, 1991).

Deneyime açıklık: Deneyime açıklık, düşünceler ve fikirler, deneyimler, duygular ve sanat da dahil olmak üzere, yaşamın her yönüne yaygın bir merak ve ilgiyi ifade eder (Costa \& McCrae, 1992, s.15). Bazı modellerde bu boyut akıl olarak tanımlanmaktadır (Goldberg, 1993). Deneyime açık kişilerin temel özellikleri yaratıcılık, bağımsızlık, duyarlı olmak, analitik düşünmek, meraklılık, farklı görüşlere açık olmak, geleneksel olmamak, güçlü hayal gücü, cesaret ve değişikliği sevmektir (Costa \& McCrae, 1992; Somer vd., 2002, Basım vd., 2009; Doğan, 2012). Bu tarz bireyler için alışverişte kendi kendini tatmin etme önemlidir (Mooradian \& Olver, 1996).

Yumuşak başlılık (geçimlilik): Yumuşak başı kişiler genellikle başkalarını düşünen bireylerdir. Başkalarına karşı anlayışı ve yardım etmeye isteklidirler. Aynı şekilde diğerlerinin de onlara yardıma etmeye istekli olacağına inanırlar. Bu boyutu oluşturan kişilerin özellikleri arasında alçak gönüllü, samimi, yardımsever, bağışlayıcı, anlayışlı, nazik, hoşgörülü, saygılı ve esnek olma gibi özellikler sıralanabilir (Costa \& McCrae, 1992; Somer vd., 2002, Basim vd., 2009) .

Dürüstlük: Dürüst bireyler, amaçları olan kararlı, titiz, dakik, güvenilir, başarılı olmaya eğilimli ve azimli bireylerdir (Costa \& McCrae, 1992, s.16). Planlama, organize etme ve görevleri yerine getirme güçleri yüksektir. 


\subsection{Araştırmanın Amacı ve Hipotezler}

$\mathrm{Bu}$ çalışmanın temel amacı perakende terapi kavramını tanımlayarak Türkçe literatüre katkıda bulunmaktır. Bir diğer amacı ise, belirlenen kişilik özelliklerinin farklı seviyelerine göre perakende terapi düzeylerinin farkl1lık gösterip göstermediğini tespit etmektir. $\mathrm{Bu}$ kapsamda araştırmanın hipotezleri şu şekilde oluşturulmuştur.

$\boldsymbol{H}_{1}$ : Kişilerin nevrotiklik düzeylerine göre perakende terapi düzeyleri farklılık gösterir.

$\boldsymbol{H}_{2}$ : Kişilerin dışadönüklük düzeylerine göre perakende terapi düzeyleri farklılık gösterir.

$\boldsymbol{H}_{3}$ : Kişilerin deneyime açıklık düzeylerine göre perakende terapi düzeyleri farklılık gösterir.

$\boldsymbol{H}_{4}$ : Kişilerin yumuşak başlılık düzeylerine göre perakende terapi düzeyleri farklılık gösterir.

$\boldsymbol{H}_{5}$ : Kişilerin dürüstlük düzeylerine göre perakende terapi düzeyleri farklılık gösterir.

\section{YÖNTEM VE BULGULAR}

\section{1. Örneklem ve Veri Toplama Tekniği}

Araştırmanın amacı; tüketici kişiliği açısından terapi tüketiminin farklılık gösterip göstermediğini araştırmaktır. Çalışmanın amaçları doğrultusunda hazırlanan anket formu yüz yüze anket yöntemi ile uygulanmıştır. Araştırmanın evrenini, Kayseri il merkezindeki tüketiciler oluşturmaktadır. Örneklem sayısı Yazıcı ve Erdoğan (2004) örneklem büyüklükleri tablosuna göre belirlenmiştir. Örneklem tesadüfî olmayan örnekleme yöntemlerinden biri olan, kolayda örnekleme yönetimi ile seçilen, 386 tüketiciden oluşmaktadır. Kolayda örneklemede veriler, ana kütleden kolay, hızlı ve ekonomik şekilde toplanabilmektedir (Zikmund, 1997, s.428). Kolayda örnekleme yönteminin kullanılmış olması nedeniyle, çalışmanın bulgularının genellenmesinde dikkatli olunmasının hatırlatılmasında yarar vardır.

\subsection{Veri Toplama Araçları}

Çalışmada geliştirilen anket formu, literatürde uygulanmış ve geçerlik ve güvenirlikleri test edilmiş ölçeklerden yararlanılarak uyarlanmıştır. Kullanılan ölçekler yabancı çalışmalardan Türkçeye çevrilerek elde edilmiştir. $\mathrm{Bu}$ sebeple veri toplamaya başlamadan önce bir pilot çalışma ile ölçeklerin muhtemel eksiklikleri giderilmeye çalışılmıştır. Bu çalışmada kolayda örnekleme yolu ile seçilen 50 kişiye anket uygulanmıştır. Pilot çalışma sonrasında anket formu tüketicilerin net olarak anlayabileceği şekilde tekrardan revize edilmiştir. Anketlerin eksiksiz cevaplanması için katılımcılara gerekli açıklamalar yapılmıştır. Anketler incelenmiş, analize uygun olmayan eksik, tutarsız ve hatalı olduğu tespit edilen veriler ayıklanmıştır. Bu işlemler sonucunda toplam kullanılabilir anket sayısı 356 adet 
olmuştur. Çalışma, tanımsal bir araştırma olup veriler SPSS 22 paket programı ile analiz edilmiştir.

Anket formu 3 bölümden oluşmaktadır. İlk iki bölümde perakende terapi ( 22 ifade) ve kişilik özelliklerini (25 ifade) tespit etmeye yönelik toplam 47 adet ifade yer almaktadır. Çalışmada kullanılan değişkenler ve bu değişkenlerin ölçülmesinde kullanılan ifadeler, hazırlanırken literatür çalışması yapılmış ve daha önce literatürde yapılan çalışmalarda geçerliliği test edilmiş ölçekler kullanılmıştır. Perakende terapi ölçeği Kang ve Johnson, (2011); Beş faktör kişilik ölçeği ise Yoo ve Gretzel, (2011) çalışmalarından uyarlanmıştır. Bu çalışmada 5'li likert tipi ölçek kullanılmıştır (1=Kesinlikle Katılmıyorum, 5= Kesinlikle Katılıyorum). Anketin son bölümünde ise demografik özellikleri tespit etmeye yönelik sorular yer almaktadır.

Ölçeklere ait iç tutarlılık anlamında güvenilirlik, Cronbach's alfa katsayısı kullanılarak test edilmiştir. Aşağıda yer alan Tablo 1'de güvenilirlik sonuçları ve ölçeklerin kaynakları yer almaktadır.

Tablo 1. Ölçeklerin İç Tutarlılık Güvenilirlik Sonuçları

\begin{tabular}{|c|c|c|}
\hline Ölçekler & Madde Sayısı & $\begin{array}{l}\text { Cronbach's } \\
\text { Alfa }\end{array}$ \\
\hline Perakende terapi ölçeği (22 madde, 4 faktör) & 22 & 927 \\
\hline 1. Faktör: Terapatik alışveriș motivasyonları & 6 & 914 \\
\hline 2. Faktör: Terapatik alışveriş değeri Pozitif duygu takviyesi & 6 & 819 \\
\hline 3. Faktör: Terapatik alışveriș değeri: Olumsuz duygudurum azaltma & 5 &, 829 \\
\hline 4. Faktör: Terapatik alışveriş sonucu & 5 &, 831 \\
\hline Nevrotiklik & 5 & ,868 \\
\hline Dişadönüklük & 5 &, 723 \\
\hline Deneyime Açıklık & 5 & ,874 \\
\hline Yumuşak başılılık & 5 & ,718 \\
\hline Dürüstlük & 5 & 868 \\
\hline
\end{tabular}

Kullanılan ölçeklerin Cronbach's alfa değerleri 0,718-0,927 arasında olduğu için ölçekler yüksek derecede güvenilirdir. Nunnally (1978) Cronbach’s alpha değerinin 0,70 ve üstü olmasının ölçeğin güvenirliği açısından yeterli olduğunu tespit etmiştir. Bu güvenilirlik katsayısı ölçeği oluşturan maddeler arasında yüksek düzeyde bir iç tutarlılık olduğunu ifade etmektedir.

\subsection{Bulgular}

Çalışmadan elde edilen veriler SPSS 22 paket programı ile analiz edilmiştir. Araştırmaya katılanların demografik özellikleri ile ilgili tanımlayıcı istatistikler Tablo 2'de verilmiştir. 
Örneklemin demografik yapısı incelendiğinde, Tablo 2'de görüldüğü gibi katılımcıların \% 54,8'i kadın ve \% 45,2'si erkek, \% 52,5'i üniversite mezunu, \% 62,8'i evli, \% 35'7'si 18-28 yaş aralığında ve \% 26,8'i 3501-6500 gelir grubundadır.

Tablo 2. Katılımcıların Demografik Özellikleri

\begin{tabular}{|c|c|c|c|c|c|}
\hline & $\begin{array}{r}\text { Frekans } \\
(\mathrm{n}=356)\end{array}$ & $\%$ & & $\begin{array}{c}\text { Frekans } \\
(\mathrm{n}=356)\end{array}$ & $\%$ \\
\hline \multicolumn{3}{|l|}{ Cinsiyet } & \multicolumn{3}{|l|}{ Yaş } \\
\hline Kadın & 195 & 54,8 & $18-28$ & 127 & 35,7 \\
\hline Erkek & 161 & 45,2 & $29-38$ & 98 & 27,5 \\
\hline \multicolumn{3}{|c|}{ Öğrenim Durumu } & $39-48$ & 92 & 18,4 \\
\hline İlköğretim & 17 & 4,8 & $49 \mathrm{ve} \uparrow$ & 59 & 16,6 \\
\hline Lise -Dengi & 119 & 33,4 & \multicolumn{3}{|l|}{ Gelir } \\
\hline Üniversite & 187 & 52,5 & 1500 ve $\downarrow$ & 24 & 7,1 \\
\hline YLS-Doktora & 33 & 9,3 & $1501-2500$ & 67 & 19,9 \\
\hline \multicolumn{3}{|c|}{ Medeni Durum } & $2501-3500$ & 83 & 24,7 \\
\hline Evli & 314 & 62,8 & $3501-6500$ & 90 & 26,8 \\
\hline \multirow[t]{2}{*}{ Bekar } & 186 & 37,2 & $6501-10000$ & 62 & 18,5 \\
\hline & & & $10000 \mathrm{ve} \uparrow$ & 10 & 3 \\
\hline
\end{tabular}

Katılımcılardan ölçeklerde yer alan ifadeleri değerlendirmeleri istenmiştir.

Değerlendirmeler ile ilgili ortalama ve standart sapma değerleri Tablo 3 ve 4 'te yeralmaktadır.

Tablo 3. Tüketicinin Perakende Terapi ile İlgili İfadelere Katılımına İlişkin Göstergeler

\begin{tabular}{|c|c|c|}
\hline Ölçekler & Ortalama & Std. sapma \\
\hline 1. Faktör: Terapatik alışveriș motivasyonları & 3,20 & \\
\hline Stresimi azaltmak için alışveriş yaparım. & 3,31 & 1,327 \\
\hline Kendimi neşelendirmek için alışveriş yaparım. & 3,36 & 1,241 \\
\hline Kendimi daha iyi hissetmek için alışveriş yaparım. & 3,31 & 1,275 \\
\hline Kötü bir günü telafi etmek için alışveriş yaparım. & 2,90 & 1,236 \\
\hline Rahatlamak için alışveriş yaparım. & 3,13 & 1,207 \\
\hline İyi hissetmek için alışveriş yaparım. & 3,20 & 1,205 \\
\hline 2. Faktör: Terapatik alışveriş değeri: Pozitif duygu takviyesi & 3,19 & \\
\hline Alışveriş, olumlu bir dikkat dağıtıcıdır. & 3,27 & 1,225 \\
\hline Alışveriş bana başarı hissi verir. & 2,57 & 1,152 \\
\hline Alışverişteki görsel uyarımlardan hoşlanırım. & 3,46 & 1,137 \\
\hline Alışveriş bana yeni stiller hakkında bilgi sağlıyor. & 3,52 & 1,148 \\
\hline Alışverişin sağladığı hoş ortamda bulunmaktan zevk alırım. & 3,16 & 1,189 \\
\hline Büyük bir şey bulmak, kendimle ilgili olumlu duygularımı güçlendirir. & 3,15 & 1,129 \\
\hline 3. Faktör: Terapatik alışveriş değeri: Negatif duygudurum azaltma & 2,69 & \\
\hline Alışveriş yalnızlıktan kaçmaktır. & 2,31 & 1,157 \\
\hline Alışveriş, stresli ortamlardan kurtulmamın bir yoludur. & 2,79 & 1,193 \\
\hline Alışveriş yapmak, beni rahatsız eden şeyleri aklımdan çıkarmanın bir yoludur. & 3,05 & 1,217 \\
\hline Yeni bir şey için alışveriş yapmak boşluk duygusunu doldurur. & 2,86 & 1,179 \\
\hline $\begin{array}{l}\text { Alışveriş, başka şeyler kontrol dışı kaldığında, işleri kontrol etmenin bir } \\
\text { yoludur. }\end{array}$ & 2,42 & 1,103 \\
\hline 4. Faktör: Terapatik alışveriş sonucu & $\mathbf{3 , 1 0}$ & \\
\hline Moralimi düzeltmek için alışveriş etkilidir. & 3,08 & 1,169 \\
\hline $\begin{array}{l}\text { Kendimi daha iyi hissetmek için yaptığım alışverişten sonra, en azından günün } \\
\text { geri kalanı için en iyi hisler oluşur. }\end{array}$ & 3,14 & 1,131 \\
\hline Moralimi düzeltmek için yaptığım alışverişten sonra kendimi iyi hissederim. & 3,18 & 1,119 \\
\hline Aldığım eşyaları moralimi düzeltmek için kullanırım. & 3,28 & 1,133 \\
\hline $\begin{array}{l}\text { Moralimi düzeltmek için yaptı̆̆ım alışveriş sırasında aldığım eşyaları } \\
\text { kullanırken, o alışveriş deneyimini hatırlarım. }\end{array}$ & 2,84 & 1,155 \\
\hline
\end{tabular}


Cevaplayıcıların perakende terapi faktörleri içinde en yüksek katılım gösterdikleri faktör terapatik alışveriş motivasyonlarıdır. Bu faktör içinde ise "Kendimi neşelendirmek için alışveriş yaparım" $(3,36)$ ve "stresimi yenmek için alışveriş yaparım" $(3,31)$ ifadelerine daha fazla katılım göstermişlerdir. Ancak “Kötü bir günü telafi etmek için alışveriş yaparım” $(2,90)$ ifadesine katılmamaktadırlar. Cevaplayıcılar perakende terapi faktörleri içinde negatif duygudurum azaltma faktörüne katılmamaktadırlar $(2,69)$. Bu faktör içinde ise en olumsuz değerlendirdikleri “Alışveriş yalnızlıktan kaçmaktır” (2,31) ifadesidir.

Tablo 4. Tüketicinin Kişilik Boyutlarıyla İlgili İfadelere Katılımına İlişkin Göstergeler

\begin{tabular}{|c|c|c|}
\hline Ölçekler & Ortalama & $\begin{array}{c}\text { Standart } \\
\text { sapma }\end{array}$ \\
\hline Nevrotiklik & 3,19 & \\
\hline Kolay strese girerim & 3,30 & 1,262 \\
\hline Endişeli biriyimdir. & 3,20 & 1,265 \\
\hline En kötüsünden korkarım. & 3,10 & 1,256 \\
\hline Şüphecibiriyimdir. & 3,34 & 1,232 \\
\hline Kolayca panik yaparım. & 2,99 & 1,267 \\
\hline Dışa dönüklük & $\mathbf{3 , 3 2}$ & \\
\hline Arkadaş toplantılarında birçok farklı insanla sohbet ederim & 3,79 & 1,059 \\
\hline Etrafımda insanlar varken rahatımdır. & 3,44 & ,980 \\
\hline Sohbetleri hep ben başlatırım. & 3,09 & ,845 \\
\hline Kolay arkadaş edinirim. & 3,52 & ,998 \\
\hline Dikkat çekmekten rahatsız olmam. & 3,24 & 1,122 \\
\hline Açık fikirlilik & 3,91 & \\
\hline Yeni fikirler beni heyecanlandırır. & 3,94 & ,933 \\
\hline Herhangi bir şey hakkında düşünmekten hoşlanırım. & 3,94 & ,922 \\
\hline Yeni fikirler duymaktan hoşlanırım. & 3,97 & ,874 \\
\hline Daha derin bir anlam aramaktan hoşlanırım. & 3,90 & ,963 \\
\hline Canlı bir hayal gücüm var. & 3,80 & 1,028 \\
\hline Yumuşak başlılık & $\mathbf{3 , 5 1}$ & \\
\hline Başkalarının duygularına sempati duyarım. & 3,68 & ,958 \\
\hline Başkaları için endişelenirim. & 3,58 & 1,003 \\
\hline Başkalarına saygı duyarım. & 3,99 & ,937 \\
\hline Diğer insanların iyi niyetli olduğuna inanırım. & 3,13 & 1,055 \\
\hline İnsanların bana söylediklerine güvenirim. & 3,16 & 951 \\
\hline Dürüstlük & $\mathbf{3 , 7 0}$ & \\
\hline Planlarımı yerine getiririm. & 3,66 & ,903 \\
\hline Detaylara dikkat ederim. & 3,92 & ,987 \\
\hline Her zaman hazırımdır. & 3,34 & 1,032 \\
\hline Yaptığım planlara sadık kalıyorum. & 3,61 & ,961 \\
\hline Yaptığım işte dikkatliyimdir. & 3,95 & ,960 \\
\hline
\end{tabular}

Yukarıda yer alan tablo 4'te görüldüğü gibi cevaplayıcılar kendilerini en çok açık fikirli olarak tanımlamaktadırlar (3,91). İkinci sırada ise dürüstlük yer almaktadır $(3,70)$.

Perakende terapi ve boyutları ile demografik değişkenler arasında istatistiki bakımdan anlamlı ilişki olup olmadığı korelasyon analizi ile araştırılmıştır. Pearson korelasyon katsayıları hesaplanmıştır. $\mathrm{Bu}$ analiz sonucu elde edilen değerler aşağıda Tablo 5'te yer almaktadır. 
Tablo 5. Perakende Terapi ile Demografik Değişkenler Arasındaki İlişkiler

\begin{tabular}{|l|l|c|c|c|c|}
\hline & & Cinsiyet & Yaş & Gelir & $\begin{array}{c}\text { Medeni } \\
\text { Durum }\end{array}$ \\
\hline \multirow{2}{*}{ Terapatik alışveriş motivasyonları } & PearsonCorrelation &,$- 512^{* *}$ &,- 076 &,- 072 &,- 018 \\
\cline { 2 - 6 } & Sig. (2-tailed) &, 000 &, 228 &, 294 &, 783 \\
\hline \multirow{2}{*}{$\begin{array}{l}\text { Terapatik alışveriş değeri: Pozitif } \\
\text { duygu takviyesi }\end{array}$} & PearsonCorrelation &,$- 159^{*}$ &,- 109 &, $112^{* *}$ &, 056 \\
\cline { 2 - 6 } $\begin{array}{l}\text { Terapatik alışveriş değeri: Negatif } \\
\text { duygudurum azaltma }\end{array}$ & Sig. (2-tailed) &, 011 &, 083 &, 003 &, 395 \\
\hline \multirow{2}{*}{ Terapatik alışveriş sonucu } & PearsonCorrelation &,- 065 &,- 073 &, $604^{* *}$ &, 191 \\
\cline { 2 - 6 } & Sig. (2-tailed) &, 300 &, 245 &, 003 &, 071 \\
\hline \multirow{2}{*}{ Perakende terapi bütün } & PearsonCorrelation &,$- 223^{* *}$ &,- 087 &, $218^{*}$ &, 062 \\
\cline { 2 - 6 } & Sig. (2-tailed) &, 000 &, 165 &, 030 &, 449 \\
\hline & PearsonCorrelation &,$- 253^{* *}$ &,- 100 &, $183^{*}$ &, 079 \\
\cline { 2 - 6 } & Sig. (2-tailed) &, 000 &, 112 &, 020 &, 227 \\
\hline
\end{tabular}

* Korelasyon 0,05 düzeyinde anlaml. Sig.(2-uçlu). $\quad * *$ Korelasyon 0,01 düzeyinde anlamll. Sig. $(2-u c ̧ l u)$.

Korelasyon analizinin sonucuna göre cevaplayıcıların demografik özelliklerinden medeni hal ve yaş ile bağımlı değişkenleri oluşturan perakende terapi ve boyutları arasında istatistiksel olarak anlamlı bir ilişki yoktur $(\mathrm{p}>0,05)$. Ancak cinsiyet ile terapatik alışveriş motivasyonları $(\mathrm{r}=-, 512)$, pozitif duygu takviyesi $(\mathrm{r}=-, 159)$, terapatik alışveriş sonucu $(\mathrm{r}=-$ ,223) ve perakende terapi $(\mathrm{r}=-$-253) arasında istatistiksel olarak anlamlı negatif yönde ilişki vardır. Demografik değişkenlerden gelir ile pozitif duygu takviyesi $(r=, 112)$, negatif duygu durum azaltma $(\mathrm{r}=, 604)$, terapatik alışveriş sonucu $(\mathrm{r}=, 218)$ ve perakende terapi $(\mathrm{r}=, 183)$ arasında istatistiksel olarak anlamlı pozitif yönde ilişki vardır. Bu sonuçlara göre kadınların ve yüksek gelirlilerin bir bütün olarak perakende terapisini daha olumlu algıladıkları söylenebilir.

Kişilik özelliklerinin farklı seviyelerine göre perakende terapi düzeylerinin farklılık gösterip göstermediğini tespit etmek amacıyla yapılan $\mathrm{t}$ testi sonuçları Tablo 6'da görülmektedir.

Tablo 6. Perakende Terapisi ile Kişilik Boyutları Arasında t Testi Sonuçları

\begin{tabular}{|l|c|c|c|c|c|c|}
\hline \multirow{2}{*}{ Kişilik Boyutları } & \multicolumn{2}{|c|}{ Ortalama } & \multirow{2}{*}{$\begin{array}{c}\text { Ortalamalar } \\
\text { Farkı }\end{array}$} & \multirow{2}{*}{ t değeri } & \multirow{2}{*}{ df } & p \\
\cline { 2 - 3 }$n$ & Düşük & Yüksek &,- 37605 & $-3,697 * *$ & 254 &, 000 \\
\hline Nevrotiklik & 2,8916 & 3,2677 &,- 19002 & $-1,853$ & 254 &, 065 \\
\hline Dışadönüklük & 2,9605 & 3,1505 &, 04366 &, 351 & 254 &, 726 \\
\hline Deneyime Açıklık & 3,0814 & 3,0378 &,- 10111 &,- 983 & 254 &, 327 \\
\hline Yumuşak başlılık & 2,9936 & 3,0947 &,- 29610 & $-2,752 * *$ & 254 &, 006 \\
\hline Dürüstlük & 2,8496 & 3,1456 & & & &
\end{tabular}

$* \mathrm{p}<.05 . \quad * * \mathrm{p}<.01$.

Her bir kişilik özelliğinin farklı düzeylerinde perakende terapi düzeyinin karşılaştırılması amacıyla yapılan $t$ testi sonucuna göre nevrotik ( $\left.t_{0,01}: 254=-3,697\right)$ ve dürüst $\left(\mathrm{t}_{0,01}\right.$ : 254=-,29610) kişilik özelliklerinin farklı seviyelerinde perakende terapi düzeyleri istatistiksel olarak anlamlı bir farklılık göstermektedir. Bu sonuçlara göre $\mathrm{H}_{1}$ ve $\mathrm{H}_{5}$ hipotezleri 
kabul edilmektedir. Daha nevrotik özellikler gösteren kişilerin perakende terapi ortalamaları $(\overline{\mathrm{x}}=3,2677)$ nevrotiklik seviyesi düşük kişilerin ortalamalarına $(\overline{\mathrm{x}}=2,8916)$ göre daha yüksektir. Daha dürüst kişilerin perakende terapi ortalamaları $(\overline{\mathrm{x}}=3,1456)$ dürüstlük seviyesi düşük kişilerden $(\bar{x}=2,8496)$ daha yüksektir. Ancak dışa dönük, deneyime açık ve yumuşak başlı kişilik özelliklerinin farklı seviyelerinde perakende terapi ortalamaları farklılık göstermemektedir $(\mathrm{p}>0.05)$. Bu sonuçlara göre $\mathrm{H}_{2}, \mathrm{H}_{3}$ ve $\mathrm{H}_{4}$ reddedilmektedir.

\section{SONUÇ}

Alışveriş bireyler için toplumsallaşmanın ve günlük yaşamla başa çıkabilmenin yeni bir yolu olabilmektedir. Günümüz toplumunda bireyler giderek yalnızlaşmakta ve yoğun stres altında yaşamakta, yaşam içinde başka hiç bir yerden sağlayamadıkları desteği alışverişte bulabilmektedirler.

Çalışmada, cinsiyet ve gelir ile perakende terapi arasında ilişki olduğu tespit edilmiştir. Bu sonuçlara göre bayanların ve yüksek gelirlilerin bir bütün olarak perakende terapisini daha olumlu algıladıkları söylenebilir. Underhill (1999) kadınların özellikle alışverişi perakende terapisi olarak kullandıklarını ve sıradan hayattan "kaçış" için alışveriş yapmaktan büyük zevk aldıklarını belirtmiştir. Bu sonuçlar, Underhill'in (1999) sonuçlarını desteklemektedir.

Nevrotik ve dürüst kişilik özelliklerinin farklı seviyelerinde perakende terapi düzeylerinin farklılık gösterdiği tespit edilmiştir. Nevrotik kişilerin perakende terapiye yönelmeleri çok daha mümkün görülmektedir. Bu sonuç, Mooradian ve Olver'ın (1996) nevrotikliğin, kendini tatmin etme ve duygu durum yönetimi ile bağlantılı alışveriş motivasyonlarıyla ilgili olması gerektiği yönündeki bulgularını desteklemektedir. Dürüst kişilik özellikleri baskın olan kişilerin de aynı şekilde perakende terapiye yönelmeleri çok daha mümkün görülmektedir. Ancak dışa dönük, deneyime açık ve yumuşak başlı kişilik özelliklerinin perakende terapi açısından farklılık göstermediği tespit edilmiştir. Literatürde sonuçları karşılaştırarak değerlendirebileceğimiz ampirik çalışmalar olmadığı için yorum yapmak güçleşmektedir.

Terapi amacıyla alışveriş yapan tüketicilerin ve motivasyonlarının tespit edilmesi perakendeciler için çok önemlidir. Bu tüketicileri ayrı bir pazar bölümü olarak düşünüp tüm pazarlama faaliyetlerini bu yeni pazar bölümüne uyarlayan perakendeciler büyük firsatlar elde edebileceklerdir. $\mathrm{Bu}$ yeni pazar bölümünün kısa vadede çok daha büyeceği ve önem kazanacağı düşünülmektedir. Wakefield ve Baker'ın (1998) belirttiği gibi perakende 
yöneticileri perakende terapide tatmini arttırabilecek unsurlara odaklanmalıdırlar. Mağaza atmosferini iyileştirmek, alış veriş deneyimini daha keyifli ve eğlenceli hale getirmek, alışveriş deneyimlerinin duygusal değerine katkıda bulunan aktiviteler sunmak gibi konulara odaklanarak terapi alışverişi yapan tüketicilerin tatminini arttırabilirler.

Her araştırmada olduğu gibi bu araştırmada da bir takım sınırlılıklar bulunmaktadır. Araştırmanın en önemli sınırlılığı seçilen örnek kütle ve araştırmanın kapsamıyla ilgilidir. $\mathrm{Bu}$ araştırma, zaman ve maliyet kısıtlarından dolayı sadece bir ildeki tüketicilerle sınırlıdır. Araştırma sadece Kayseri ilinde gerçekleştirilmiştir. Çalışmada kolayda örnekleme yönteminin kullanılması ise bir başka kısıtı oluşturmaktadır. Tesadüfi örneklemenin yapılmamış olması nedeniyle bulgularla ilgili tüm tüketicilere ya da tüketici gruplarına genellemeler yapılırken dikkatli olunmalıdır.

Gelecek çalışmalarda konu farklı değişkenler açısından da incelenebilir. Özellikle materyalist eğilimi yüksek kişiler maddi varlıklarla mutluluğu yakalama çabası içinde olduklarından terapi tüketimine daha yatkın olabilecekleri düşünülmektedir. $\mathrm{Bu}$ sebeple materyalizm ve terapi tüketimi bir arada incelenebilir. Ayrıca, perakende terapide niyeti etkileyebilecek marka imajı, marka kalitesi, mağaza atmosferi gibi diğer faktörlerde dikkate alınarak yürütülecek çalışmalarla konu daha iyi kavranabilir.

Yeni yeni çalışılan bu kavramın hem pazarlama hem de psikoloji bilimi için giderek öneminin artacağına inanılmaktadır. Bu konuda yürütülecek disiplinlerarası yeni çalışmalarla konunun kavramsal ve olgusal kanıtlarının artacağı düşünülmektedir. 


\section{KAYNAKÇA}

Andrade, E.B. (2005). Behavioural consequences of affect: combining evaluative and regulatory mechanisms, Journal of Consumer Research, 32 (12), 355-362.

Atalay, S., \& Meloy, M. (2006). When the going gets tough, the tough go shopping: An examination of selfgifting behavior. ACR North American Advances, 258-260.

Atalay, A. S., \& Meloy, M. G. (2011). Retail therapy: A strategic effort to improve mood. Psychology \& Marketing, 28(6), 638-659.

Atkinson, R. L., Atkinson, R., \& Hilgard, E. (1995). Psikolojiye Giriş I-II. K. Atakay vd. (Çev.). İstanbul: Sosyal Yayınları.

Babin, B. J., Darden, W. R., \& Griffin, M. (1994). Work and/or fun: measuring hedonic and utilitarian shopping value. Journal of Consumer Research, 20(4), 644-656.

Bacanlı, H., İlhan, T., \& Aslan, S. (2009). Beş Faktör Kuramına Dayalı Bir Kişilik Ölçeğinin Geliştirilmesi: Sıfatlara Dayalı Kişilik Testi (SDKT). Türk Ĕ̆itim Bilimleri Dergisi, 7(2), 261-279.

Barrick, M. R., \& Mount, M. K. (1991). The big five personality dimensions and job performance: a metaanalysis. Personnel psychology, 44(1), 1-26.

Basım, H. N., Çetin, F., \& Tabak, A. (2009). Beş faktör kişilik özelliklerinin kişilerarası çatışma çözme yaklaşımlarıyla ilişkisi. Türk Psikoloji Dergisi, 24(63), 20-34.

Benet-Martinez, V., \& John, O. P. (1998). Los Cinco Grandes across cultures and ethnic groups: Multitraitmultimethod analyses of the Big Five in Spanish and English. Journal of personality and social psychology, 75(3), 729-750.

Block, J. (1995). A contrarian view of the five-factor approach to personality description. Psychological bulletin, 117(2), 187-215.

Bui, M., \& Kemp, E., (2013). E-tail emotion regulation: examining online hedonic product purchases, International Journal of Retail \& Distribution Management, 41(2), 155-170.

Costa Jr, P. T., \& McCrae, R. R. (1992). Four ways five factors are basic. Personality and Individual Differences, 13(6), 653-665.

Digman, J. M. (1990). Personality structure: Emergence of the five-factor model. Annual review of psychology, 41(1), 417-440.

Doğan, T. (2012). Beş faktör kişilik özellikleri ve öznel iyi oluş. Doğuş Üniversitesi Dergisi, 14(1), 56-64.

Faber, R. J., \& Christenson, G. A. (1996). In the mood to buy: Differences in the mood states experienced by compulsive buyers and other consumers. Psychology \& Marketing, 13(8), 803-819.

Gardner, M. P., \& Rook, D. W. (1988). Effects of impulse purchases on consumers' affective states. Advances in Consumer Research, 15, 127-130.

Goldberg, L. R. (1993). The structure of phenotypic personality traits. American Psychologist, 48(1), 26-34. 
Gökdeniz, İ., Durukan, T., \& Bozac1, İ. (2012). Müşterinin firmaya şikâyet etme eğilimini etkileyen bireysel faktörler üzerine uygulamalı bir çalı̧̧ma. Aksaray Üniversitesi İktisadi ve İdari Bilimler Fakültesi Dergisi, 4(1), 17-36.

Jamal, F. D., Chudry, F. \& Al-Marri, M. (2006). Profiling consumers: A study of Qatari consumers' shopping motivations. Journal of Retailing and Consumer Services, 13(1), 67-80.

John, O.P. (1990) The "Big Five" factor taxonomy: Dimensions of personality in the natural language and in questionnaires. In: Pervin, L.A., Ed., Handbook of Personality: Theory and Research, Guilford Press, New York, 1990, 66-100.

Kacen, J. J. (1998). Retail therapy: Consumers' shopping cures for negative moods. Advances in Consumer Research, 25(1), 75-87.

Kacen, J. J., \& Friese, S. (1999). An exploration of mood-regulating consumer buying behavior. European Advances in Consumer Research, 4(1), 75-76.

Kang, M., \& Johnson, K. K. (2010). Let's shop! Exploring the experiences of therapy shoppers. Journal of Global Fashion Marketing, 1(2), 71-79.

Kang, M., \& Johnson, K. K. P. (2011). Retail Therapy: Scale Development. Clothing and Textiles Research Journal, 29(1), 3-19.

Kemp, E., \& Kopp, S. W. (2011). Emotion regulation consumption: When feeling better is the aim. Journal of Consumer Behaviour, 10(1), 1-7.

Kim, S., \& Gal, D. (2014). From compensatory consumption to adaptive consumption: The role of selfacceptance in resolving self-deficits. Journal of Consumer Research, 41(2), 526-542.

Kim, S., \& Rucker, D. D. (2012). Bracing for the psychological storm: Proactive versus reactive compensatory consumption. Journal of Consumer Research, 39(4), 815-830.

Ko, E., Chun, E., Song, S., \& Mattila, P. (2015). Exploring SNS as a consumer tool for retail therapy: Explicating semantic networks of "shopping makes me happy (unhappy)" as a new product development method. Journal of Global Scholars of Marketing Science, 25(1), 37-48.

Köknel, Ö. (2005). Kaygıdan Mutluluğa Kişilik, 17. Bs., İstanbul: Altın Kitaplar Yayınevi.

Krishen, A. S., Bui, M., \& Peter, P. C. (2010). Retail kiosks: How regret and variety influence consumption. International Journal of Retail \& Distribution Management, 38(3), 173-189.

Lonsdale, S. (1994). Shopping as therapy. Star Tribune, 11, 1-13.

Luomala, H. T. (1998). A mood-alleviative perspective on self-gift behaviours: Stimulating consumer behaviour theory development. Journal of Marketing Management, 14(1-3), 109-132.

Luomala, H. T., Kumar, R., Worm, V., \& Singh, J. D. (2004). Cross-cultural differences in mood-regulation: An empirical comparison of individualistic and collectivistic cultures. Journal of International Consumer Marketing, 16(4), 39-62.

Mandel, N., Rucker, D. D., Levav, J., \& Galinsky, A. D. (2017). The compensatory consumer behavior model: How self-discrepancies drive consumer behavior. Journal of Consumer Psychology, 27(1), 133-146. 
McCrae, R. R., \& Costa, P. T. (1983). Social desirability scales: More substance than style. Journal of consulting and clinical psychology, 51(6), 882-888.

McCrae, R. R., \& John, O. P. (1992). An introduction to the five-factor model and its applications. Journal of personality, 60(2), 175-215.

Mick, D. G., DeMoss, M., \& Faber, R. J. (1992). A projective study of motivations and meanings of self-gifts: Implications for retail management. Journal of Retailing, 68(2), 122-145.

Mooradian, T. A., \& Olver, J. M. (1996). Shopping motives and the five factor model: An integration and preliminary study. Psychological Reports, 78(2), 579-592.

Mooradian, T. A., \& Olver, J. M. (1996). Shopping motives and the five factor model: An integration and preliminary study. Psychological Reports, 78(2), 579-592.

Nunnally, J. C. (1978). Psychometric methods. New York: McGraw Hill.

Özcan, B. (2007). Postmodernizmin tüketim imajları. Fırat Üniversitesi Sosyal Bilimler Dergisi, 17(1), 261-273.

Rath, T. (2010). Your spending and your financial wellbeing. Gallup Management Journal Online, 1.

Rick, S. I., Pereira, B., \& Burson, K. A. (2014). The benefits of retail therapy: Making purchase decisions reduces residual sadness. Journal of Consumer Psychology, 24(3), 373-380.

Robins, N. (1999). Making sustainability bite: transforming global consumption patterns. Journal of Sustainable Product Design, 7-16.

Rook, D. W., \& Gardner, M. P. (1993). In the mood: impulse buying's affective antecedents. Research in consumer behavior, 6(7), 1-28.

Rucker, D. D., \& Galinsky, A. D. (2008). Desire to acquire: Powerlessness and compensatory consumption. Journal of Consumer Research, 35(2), 257-267.

Sivanathan, N., \& Pettit, N. C. (2010). Protecting the self through consumption: Status goods as affirmational commodities. Journal of Experimental Social Psychology, 46(3), 564-570.

Son, J. \& Chang, H. J. J., (2016). Retail Therapy: What Makes You Feel Relieved and Happy? International Textile and Apparel Association (ITAA) Annual Conference Proceedings. 54.

Somer, O., Korkmaz, M., \& Tatar, A. (2002). Beş Faktör Kişilik Envanteri’nin geliştirilmesi-I: Ölçek ve alt ölçeklerin oluşturulması. Türk Psikoloji Dergisi, 17(49), 21-33.

Thayer, R. E., Newman, J. R., \& McClain, T. M. (1994). Self-regulation of mood: Strategies for changing a bad mood, raising energy, and reducing tension. Journal of Personality and Social Psychology, 67(5), 910-925.

Underhill, P. (2009). Why we buy: The science of shopping--updated and revised for the Internet, the global consumer, and beyond. Simon and Schuster, New York.

Uyar K. \& Lekesizcan F. S. (2017). Markanın benliği ifade etmesi ve sosyal görünürlüğünün marka aşk1 ile ilişkisi, Business \& Management Studies: An International Journal (BMIJ), 5(4), 154-171. 
Wakefield, K. L., \& Baker, J. (1998). Excitement at the mall: determinants and effects on shopping response. Journal of retailing, 74(4), 515-539.

Weinberg, P., \& Gottwald, W. (1982). Impulsive consumer buying as a result of emotions. Journal of Business research, 10(1), 43-57.

Woodruffe-Burton, H. R. (1997). Compensatory consumption: why women go shopping when they're fed up and other stories. Marketing Intelligence \& Planning, 15(7), 325-334.

Woodruffe-Burton, H.R., \& Elliott, R. (2005). Compensatory consumption and narrative identity theory. ACR North American Advances.

Woodruffe-Burton, H., Eccles, S., \& Elliott, R. (2002). Towards a theory of shopping: A holistic framework. Journal of Consumer Behaviour: An International Research Review, 1(3), 256-266.

Yanbast, G. (1991). Theories of personality. Ege University Faculty of Education press, Izmir.

Yoo, K.H., \& U. Gretzel. (2011). Influence of personality on travel related consumer-generated media creation CHB, 27, 609-621.

Yurchisin, J., Yan, R. N., Watchravesringkan, K., \& Chen, C. (2008). Investigating the role of life status changes and negative emotions in compensatory consumption among college students. College Student Journal, 42(3), 860-869. 